\title{
Outbreaks of human coronavirus in a paediatric and neonatal intensive care unit
}

\author{
Arnaud Gagneur • Sophie Vallet • Pierre J. Talbot • \\ Marie-Christine Legrand-Quillien • Bertrand Picard • \\ Christopher Payan • Jacques Sizun
}

Received: 19 October 2007 / Accepted: 6 February 2008 / Published online: 12 March 2008

(C) Springer-Verlag 2008

\begin{abstract}
Human coronavirus 229E (HCoV) has been recently recognized as a potential agent of nosocomial viral respiratory infections (NRVI) in high-risk infants. We have confirmed this as fact through the study of a 1-year period of $\mathrm{HCoV}$ outbreaks occurring during a prospective survey of NRVI in a paediatric and neonatal intensive care unit (PNICU) using new molecular techniques for $\mathrm{HCoV}$ detection. Nasal samples obtained at admission and weekly thereafter for all hospitalised children, as well as monthly nasal samples from staff, were analysed using immunofluorescence for respiratory syncitial virus (RSV), influenza viruses $\mathrm{A}$ and $\mathrm{B}$, paramyxoviruses 1, 2, 3 and adenoviruses. RT-PCR was used for $\mathrm{HCoV}$ detection. During the year 1998, 43 HCoV-related NRVI were detected in 152
\end{abstract}

\footnotetext{
A. Gagneur $\cdot$ J. Sizun

Department of Paediatrics,

EA 3882 Laboratory of Biodiversity and Microbial Ecology,

University Hospital,

Brest, France

S. Vallet · M.-C. Legrand-Quillien · B. Picard · C. Payan Department of Microbiology,

EA 3882 Laboratory of Biodiversity and Microbial Ecology, University Hospital,

Brest, France

P. J. Talbot

Laboratory of Neuroimmunovirology,

INRS-Institut Armand-Frappier, University of Quebec,

Laval, Quebec, Canada

\section{A. Gagneur $(\bowtie)$}

Unité de Réanimation Pédiatrique et Néonatalogie,

Département de Pédiatrie CHU,

29609 Brest, France

e-mail: arnaud.gagneur@chu-brest.fr
}

neonates (incidence 28.3\%), and $7 \mathrm{HCoV}$-related NRVI were found in 92 children (incidence 7.6\%). Three HCoVrelated outbreaks were observed (February, August and December), associated with a high prevalence of $\mathrm{HCoV}$ infection in the staff. During the August outbreak, $50 \%$ to $78 \%$ of hospitalised neonates and children were infected. Seventy-five percent of hospitalised preterm neonates with a gestational age less than 32 weeks and $52.4 \%$ of staff members were infected. Risk factors for NRVI in neonates were birth weight, gestational age, ventilation, oxygenation and hospitalisation length. Ninety-two percent of infected preterm neonates were symptomatic, mainly with bradycardia and respiratory worsening. These data provide additional evidence for a possibly significant role of $\mathrm{HCoV}$ in NRVI in a PNICU. The role of staff or hospitalised children in spreading $\mathrm{HCoV}$ is hypothesised.

Keywords Human coronavirus · Outbreak · Neonates · Nosocomial infection $\cdot$ PNICU

\section{Introduction}

Human coronaviruses ( $\mathrm{HCoV})$ are widespread enveloped RNA viruses, responsible for one-third of common colds in adults [25]. Their pathogenic role in children has been unclear essentially due to difficulties in virological diagnosis. Molecular biological methods offer a new approach to monitoring these infections and establishing their medical importance [30]. Recently, there has been renewed interest in $\mathrm{HCoV}$ due to the identification of a novel coronavirus associated with severe acute respiratory syndrome (SARS) in 2002-2003 [17]. Since then, two new human coronaviruses, HKU1 and NL63, have been identified in children. Two other $\mathrm{HCoV}$ have been known for more than 40 years 
(HCoV-229E and HCoV-OC43) [13, 21], and only recently has $\mathrm{HCoV}-229 \mathrm{E}$ been recognized as a potential agent of nosocomial viral respiratory infections (NRVI) in high-risk infants [9, 31], including neonates [10, 32, 33].

We have now confirmed this through the study of outbreaks of $\mathrm{HCoV}$ infections occurring during a prospective survey of nosocomial viral respiratory infections in a paediatric and neonatal intensive care unit (PNICU), in a 1year period, using new molecular techniques for $\mathrm{HCoV}$ detection [38].

\section{Materials and methods}

\section{Setting}

The Brest University Hospital Paediatric and Neonatal Intensive Care Unit is a level 3 unit of ten single rooms and two double rooms. Each room communicates with a central corridor and nursing station. The nurse-to-patient ratio is 1 to 2 .

Visitor policy imposed no restrictions on time or duration of parental visits; siblings and other relatives were not accorded visitation at the time of this study.

As infection control policy, hands were washed before and after contact with each patient. Individual gowns and masks were routinely used during each caregiving interaction.

\section{Patients and specimens}

The nasal specimens used in this study were clinical specimens from a prospective survey of NRVI in the PNICU occurring between November 1997 and December 2001. The HCoV outbreak period studied was from 1 January 1998 to 31 December 1998. Nasal specimens were collected upon admission and thereafter on a weekly basis from all hospitalised children using a cytological brush [3]. Nasal specimens were taken from nursing staff and physicians using the same methods at nine prevalence points during the year.

\section{Case definitions}

Nosocomial infection was defined as a negative specimen upon admission with a subsequent positive viral detection, community-acquired infection as a positive viral detection upon admission. Neonates were defined as aged less than or equal to 28 days, and children as older than 28 days.

Clinical events associated with a viral infection were defined as events that occurred for a period of 3 days prior to and following the positive sample.
Virological investigations

\section{Molecular detection of $\mathrm{HCOV}-229 \mathrm{E}$}

Details of the laboratory method have been described previously, consisting of an HCoV-229E RT-PCRhybridisation assay suitable for screening large numbers of clinical samples. This procedure is reproducible, sensitive and specific [38].

Detection of other human respiratory pathogenic viruses

Each clinical sample was tested by indirect immunofluorescence (monoclonal antibody, Argene, Varhiles, France) to detect RSV, influenza viruses types $\mathrm{A}$ and $\mathrm{B}$, parainfluenza viruses types 1, 2 and 3, and adenovirus. Each specimen was also inoculated onto conventional viral cell cultures, and immunofluorescence was performed at day 3 , 5 to 7 and 10, respectively, for influenza virus (MDCK), RSV and adenovirus (Hep2 cells and MRC5) detection.

Statistical analysis

Clinical and epidemiological data were processed using Epi-Info software (CDC, USA; French version ENSP). Comparisons between groups were performed using chisquare test or Fisher exact test for categorical data and using Mann-Whitney non-parametric test for continuous variables. Significance was defined as $\mathrm{p}<0.05$.

\section{Results}

From 1 January 1998 to 31 December 1998, 244 children were admitted to the PNICU (152 neonates and 92 infants) and 592 nasal specimens were analysed. Of the 152 neonates, 103 were preterm infants with a mean gestational age of 30.9 weeks $( \pm 3.1)$ and birthweight of $1,593 \mathrm{~g}( \pm 613)$ (Table 1). Intubation occurred respectively in $66.4 \%$ and $42.4 \%$ of admitted neonates and children.

HCoV-229E was the only virus found in NRVI, with 43 infected neonates detected among 152 hospitalised neonates (incidence 28.3\%) and 7 infected children among 92 children (7.6\%). Forty-seven $\mathrm{HCoV}$ infections were noted in these 43 neonates; 4 neonates subsequently presented a second $\mathrm{HCoV}$ nosocomial infection during hospitalisation. Thirty-three children were admitted with a communityacquired respiratory infection involving $26 \mathrm{HCoV}, 7 \mathrm{RSV}, 5$ influenza $\mathrm{A}$ and 3 adenovirus A. Co-infections involving two viruses were diagnosed in eight children (Table 2). Nosocomial transmission of RSV, influenza and adenovirus was not detected in the study. 
Table 1 Characteristics of neonates and children

\begin{tabular}{|c|c|c|c|c|}
\hline & \multicolumn{2}{|l|}{ Neonates } & \multicolumn{2}{|l|}{ Children } \\
\hline & \multicolumn{2}{|l|}{$\mathrm{n}=152$} & \multicolumn{2}{|l|}{$\mathrm{n}=92$} \\
\hline & $\mathrm{HCoV}+(\mathrm{n}=43)$ & $\mathrm{HCoV}-(\mathrm{n}=109)$ & $\mathrm{HCoV}+(\mathrm{n}=7)$ & $\mathrm{HCoV}-(\mathrm{n}=85)$ \\
\hline Gender male/female & $22 / 21$ & $77 / 32$ & $4 / 3$ & $55 / 30$ \\
\hline Birthweight (g) & $1,596 \pm 968^{*}$ & $2,305 \pm 905^{*}$ & & \\
\hline Gestational age (w) & $31.1 \pm 5^{*}$ & $34.3 \pm 4 *$ & & \\
\hline Pulmonary pathology at admission (\%) & $29(67.4)$ & $68(62.4)$ & $2(28.6)$ & $30(35.3)$ \\
\hline Cardiac pathology at admission (\%) & $5(11.6)$ & $10(9.1)$ & $1(14.3)$ & $14(16.5)$ \\
\hline Intubation $(\%)$ & $33(76.7)$ & $69(63.3)$ & $7 *(100)$ & $30 *(35.3)$ \\
\hline Central venous catheter $(\%)$ & $41 *(95.4)$ & $78 *(71.5)$ & $6^{*}(85.7)$ & $21 *(24.7)$ \\
\hline Age $<3$ months $(\%)$ & $43(100)$ & $109(100)$ & $2(28.6)$ & $16(18.8)$ \\
\hline Immunodeficiency & 1 & 1 & $1(14.3)$ & $9(10.6)$ \\
\hline Death & $7(16.3)$ & $6(5.5)$ & $0(0)$ & $5(5.9)$ \\
\hline
\end{tabular}

$* \mathrm{p}<0.05$

Nosocomial coronavirus infections occurred in 43 neonates with 34 preterm infants (13 extremely premature neonates $<28$ weeks). Thirty-two of the $43 \mathrm{HCoV}$-infected neonates were symptomatic at time of infection, notably 26 of the 34 preterm newborns (Table 3). Respiratory worsening was the most frequent sign of infection with ventilatory support needed in 20 cases (46.5\%) and increase in oxygen therapy in 22 cases (51\%). Bradycardia, hypotension and prescription of antibiotics for sepsis-like syndrome were noted, respectively, in eight, three and seven cases. The mean age of neonates at the time of initial virus recovery was 14 days (median: 10 days, range: 3 to 55 days), and the mean duration of virus shedding was 5.8 days (median: 1 day; range: 1 to 36 days) (Table 3). Risk factors for $\mathrm{HCoV}$ nosocomial infections were low birthweight and low gestational age (GA). The clinical features and outcomes during hospitalisation in the $\mathrm{HCoV}$ infected and non-infected neonates were significantly different. $\mathrm{HCoV}$-infected neonates required a significantly

Table 2 Virus detection during the $\mathrm{HCoV}$ outbreak period from 1 January 1998 to 31 December 1998

\begin{tabular}{lll}
\hline Virus & $\begin{array}{l}\text { Community-acquired } \\
\text { infection }\end{array}$ & $\begin{array}{l}\text { Nosocomial } \\
\text { infection }\end{array}$ \\
\hline RSV & 7 & - \\
Influenza A & 5 & - \\
Influenza B & - & - \\
Parainfluenza 1 & - & - \\
Parainfluenza 2 & - & - \\
Parainfluenza 3 & - & - \\
Adenovirus & 3 & - \\
Human coronavirus 229E & 26 & 54 \\
Total & 41 & 54 \\
\hline
\end{tabular}

higher number of days of ventilation, oxygen supplementation and hospitalisation (Table 4).

$\mathrm{HCoV}$-related nosocomial infections occurred during every month of the study. Three outbreak periods were observed in February, August and December, during which more than $50 \%$ of hospitalised neonates and children were infected, in association with a high prevalence of infection in staff (Fig. 1). During these three outbreaks a maximum of $90 \%$ (February), 78\% (August) and 75\% (December) of hospitalised neonates and children were infected at the same time (Fig. 2). During the August period, 50 to $78 \%$ of hospitalised patients were infected over a 1-month period. Seventy-five percent of hospitalised preterm neonates with GA $<32$ weeks and $55 \%$ of staff members were infected.

A total of 180 samples were collected from the staff with $59 \mathrm{HCoV}$ samples and 1 influenza A-positive sample. Between 8 and $44 \%$ of the staff had shown respiratory illness in the week before the prevalence point. There was no significant association between a nasal HCoV-positive sample and a recent respiratory illness. For instance, in January and February, only 2 of the 13 and $14 \mathrm{HCoV}$ positive staff members had had a recent history of respiratory illness. A high prevalence of $\mathrm{HCoV}$ infection was noted in the staff during the three $\mathrm{HCoV}$-related outbreaks, with respectively $58.3 \%, 55 \%$ and $21.4 \%$ (Table 5).

\section{Discussion}

Numerous epidemics of viral infection have been described in NICU (neonatal intensive care units) involving RSV, influenza, parainfluenza, adenovirus and enterovirus. These have been retrospective descriptions. Having previously 
Table 3 Clinical characteristics of $\mathrm{HCoV}$-infected neonates

\begin{tabular}{|c|c|c|c|c|c|c|c|c|c|c|c|c|}
\hline Neonates & $\begin{array}{l}\text { Birth } \\
\text { Weight } \\
\text { (g) }\end{array}$ & $\begin{array}{l}\text { Gestational } \\
\text { age } \\
\text { (weeks) }\end{array}$ & $\begin{array}{l}\text { Age } \\
\text { (days) } \\
\text { at time } \\
\text { of } \mathrm{HCoV} \\
\text { isolation }\end{array}$ & $\begin{array}{l}\text { Days of } \\
\text { virus } \\
\text { shedding }\end{array}$ & $\begin{array}{l}\text { Clinical } \\
\text { worsening }\end{array}$ & $\begin{array}{l}\text { Ventilatory } \\
\text { support } \\
\text { (intubation } \\
\text { or CPAP) }\end{array}$ & $\begin{array}{l}\text { Increased } \\
\text { oxygen } \\
\text { therapy }\end{array}$ & Bradycardia & Hypotension & $\begin{array}{l}\text { Antibiotic } \\
\text { prescription }\end{array}$ & Death & Outbreaks ${ }^{\S}$ \\
\hline 1 & 1,300 & 29 & 18 & 1 & + & + & + & - & - & - & - & $\mathrm{F}$ \\
\hline 2 & 780 & 27 & 36 & 1 & + & + & + & - & + & - & - & $\mathrm{F}$ \\
\hline 3 & 500 & 29 & 29 & 36 & + & + & + & + & - & + & - & $\mathrm{F}$ \\
\hline 4 & 3,560 & 40 & 6 & 1 & + & - & - & - & - & - & + & $\mathrm{F}$ \\
\hline 5 & 2,740 & 41 & 4 & 1 & + & + & - & - & - & + & - & $\mathrm{F}$ \\
\hline 6 & 760 & 27 & 23 & 15 & - & - & - & - & - & - & - & \\
\hline 7 & 1,060 & 27 & 15 & 8 & + & + & + & - & - & - & - & $\mathrm{F}$ \\
\hline 8 & 1,260 & 29 & 19 & 1 & + & + & + & - & - & - & - & \\
\hline 9 & 1,260 & 31 & 22 & 1 & + & + & + & - & - & - & - & \\
\hline 10 & 860 & 26 & 19 & 8 & + & + & + & + & - & + & - & \\
\hline 11 & 1,500 & 29 & 13 & 1 & + & - & - & + & - & - & - & \\
\hline 12 & 900 & 32 & 7 & 1 & - & - & - & - & - & - & - & \\
\hline 13 & 3,120 & 38 & 13 & 1 & + & + & + & - & - & - & - & \\
\hline 14 & 680 & 27 & 36 & 1 & + & + & + & + & - & + & - & \\
\hline 15 & 920 & 26 & 32 & 25 & + & - & - & + & - & - & - & \\
\hline 16 & 1,280 & 29 & 6 & 1 & - & - & - & - & - & - & - & \\
\hline 17 & 1,880 & 32 & 4 & 1 & + & + & + & + & - & - & - & \\
\hline 18 & 1,560 & 30 & 33 & 1 & + & - & + & - & - & - & - & A \\
\hline 19 & 1,160 & 30 & 4 & 8 & + & + & + & - & - & - & - & A \\
\hline 20 & 1,440 & 30 & 4 & 9 & - & - & - & - & - & - & - & A \\
\hline 21 & 2,660 & 40 & 3 & 1 & - & - & - & - & - & - & - & A \\
\hline 22 & 1,560 & 31 & 10 & 1 & - & - & - & - & - & - & - & A \\
\hline 23 & 1,460 & 29 & 7 & 19 & - & - & - & - & - & - & - & A \\
\hline 24 & 935 & 26 & 7 & 1 & + & + & - & - & - & - & + & A \\
\hline 25 & 905 & 26 & 7 & 1 & + & - & - & - & - & - & + & A \\
\hline 26 & 2,260 & 34 & 6 & 29 & + & - & - & - & - & + & - & A \\
\hline 27 & 3,310 & 37 & 3 & 8 & + & + & + & - & + & - & - & A \\
\hline 28 & 3,100 & 38 & 3 & 1 & - & - & - & - & - & - & - & $\mathrm{A}$ \\
\hline 29 & 740 & 25 & 55 & 1 & + & - & + & - & - & - & - & \\
\hline 30 & 2,400 & 36 & 4 & 1 & - & - & - & - & - & - & - & A \\
\hline 31 & 1,260 & 32 & 21 & 1 & + & + & + & - & - & - & - & \\
\hline 32 & 2,575 & 35 & 6 & 1 & + & + & + & - & - & - & - & \\
\hline 33 & 1,740 & 30 & 3 & 1 & - & - & - & - & - & - & - & \\
\hline 34 & 820 & 29 & 15 & 1 & + & + & + & + & - & - & - & $\mathrm{D}$ \\
\hline 35 & 880 & 29 & 19 & 14 & + & - & - & - & + & - & - & $\mathrm{D}$ \\
\hline 36 & 1,160 & 26 & 12 & 7 & + & - & + & - & - & - & - & \\
\hline 37 & 800 & 26 & 38 & 1 & + & + & + & - & - & + & - & $\mathrm{D}$ \\
\hline 38 & 760 & 26 & 34 & 7 & + & - & + & - & - & - & - & $\mathrm{D}$ \\
\hline 39 & 2,900 & 39 & 6 & 1 & - & - & - & - & - & - & - & $\mathrm{D}$ \\
\hline 40 & 1,740 & 30 & 5 & 1 & + & + & + & - & - & - & - & $\mathrm{D}$ \\
\hline 41 & 3,280 & 40 & 11 & 1 & + & + & + & - & - & + & - & $\mathrm{D}$ \\
\hline 42 & 880 & 26 & 8 & 32 & + & - & - & + & - & - & - & $\mathrm{D}$ \\
\hline \multirow[t]{2}{*}{43} & 1,980 & 38 & 5 & 1 & - & - & - & - & - & - & - & $\mathrm{D}$ \\
\hline & $1,596^{*}$ & $31.1^{*}$ & $14,7^{*}$ & $5,9^{*}$ & $31^{\mu}$ & $20^{\mu}$ & $22^{\mu}$ & $8^{\mu}$ & $3^{\mu}$ & $7^{\mu}$ & $3^{\mu}$ & \\
\hline
\end{tabular}

${ }^{*}$ Mean, ${ }^{\mu}$ total, ${ }^{\S}$ outbreaks, F: February, A: August, D: December

described the existence of $\mathrm{HCoV}$ respiratory infections in premature infants, the present study reveals outbreaks of human coronaviruses for the first time. This description is extensive as it falls within the framework of a program of prospective study of respiratory viral infections within the unit. However, the real incidence of NRVI could have been underestimated, as (1) conventional methods used to detect RSV, influenza, parainfluenza and adenovirus are less 
Table 4 Clinical features and outcomes of $\mathrm{HCoV}$-infected and noninfected neonates

\begin{tabular}{llll}
\hline & $\begin{array}{l}\mathrm{HCoV}+ \\
(\mathrm{n}=43)\end{array}$ & $\begin{array}{l}\mathrm{HCoV}- \\
(\mathrm{n}=109)\end{array}$ & $\mathrm{P}$ \\
\hline Intubation duration (d) & $14 \pm 15$ & $2.4 \pm 3.7$ & $<0.001$ \\
Ventilation duration (d) & $18.8 \pm 20$ & $2.7 \pm 3.8$ & $<0.001$ \\
Oxygen duration (d) & $18.7 \pm 23.7$ & $2.5 \pm 3.3$ & $<0.001$ \\
CVC duration (d) & $28.1 \pm 26.7$ & $5.7 \pm 7.3$ & $<0.001$ \\
Antibiotic treatment duration (d) & $13 \pm 13.8$ & $3.9 \pm 3.4$ & $<0.001$ \\
Surgery & $10 / 43$ & $12 / 109$ & 0.04 \\
Hospitalisation (d) & $36.8 \pm 30.4$ & $8.8 \pm 7.6$ & $<0.001$ \\
\hline
\end{tabular}

sensitive than PCR and (2) screening for rhinovirus and other recently identified respiratory viruses such as metapneumovirus [26], bocavirus [2] and HCoV-NL63, and HKU1 was not performed.

The lack of knowledge of $\mathrm{HCoV}$ epidemiology could be explained by an absence of effective diagnostic methods. Most epidemiological studies conducted mainly in the 1970s used serological assays to detect coronavirus infection [24]. To test for $\mathrm{HCoV}$ infection in the course of large-scale epidemiological studies, we used the RT-PCRhybridisation method for rapid, specific, and more sensitive detection of $\mathrm{HCoV}$ nucleic acids [38]. By this molecular approach, two novel HCoVs, HKU1 and NL63, originating in the Netherlands, were recently identified as responsible for respiratory infections in children [6,39].

The two other human serogroups, HCoV-229E and OC43, are widespread and found in one third of common colds in children and adults [25]. They have been detected in nasal swab samples from patients with acute flu-like illness [20]. It has been suggested that they may also be involved in the etiology of more severe diseases in all age groups (pneumonia, perimyocarditis, etc.) [29] and neurological diseases such as multiple sclerosis [4]. The ability of coronaviruses to cause severe disease in animals raises the possibility that these could also cause more severe disease in humans. SARS-related coronavirus is a dramatic example of a coronavirus associated with severe disease in humans [17], demonstrating the need to consider these pathogens as of possible medical importance.

In paediatric units, the pathogenic role of $\mathrm{HCoV}$ remains undefined. They are suspected of being involved in the exacerbation of asthma in children $[8,16,40]$. Chany et al. reported an outbreak of necrotising enterocolitis occurring in near-term infants [5]. However, their role in gastrointestinal disease remains unproven [28]. Recently, the newest members of the genus coronavirus, $\mathrm{HCoV}$ NL63 and HKU1, have also been linked to respiratory tract infections such as bronchiolitis, upper and lower respiratory tract infections [11, 14, 19] and even severe obstructive pneumonia [18]. Enteric disease was also described by Vabret et al. [36, 37].

We have previously shown the potentially significant pathogenic role of $\mathrm{HCoV}$ in neonates [9, 10, 31-33]. In 1995, a prospective study showed $\mathrm{HCoV}$ incidence at $25 \%$ in symptomatic preterm neonates under 32 weeks of gestational age [32]. A prospective observational study was carried out to determine the role of $\mathrm{HCoV}$ in nosocomial infections in a paediatric ICU from 1997 to 2001 [38]. Preliminary results showed an 11\% incidence during the first winter $[9,10]$. These studies were based on indirect immunofluorescence; however, the RT-PCRhybridisation method has since provided a more rapid, specific and more sensitive analysis of these $\mathrm{HCoV}$-related outbreaks.

During this 1-year prospective study, $\mathrm{HCoV}$ was identified as the main pathogen responsible for community-

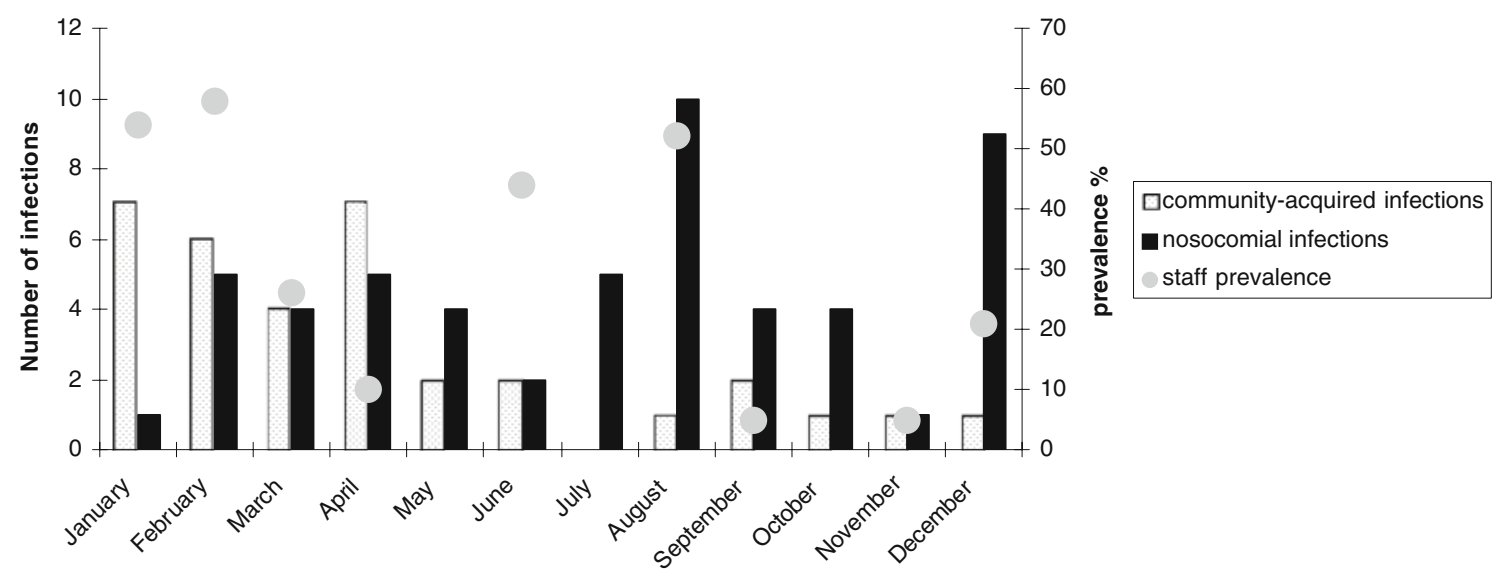

Fig. 1 Distribution of community-acquired and nosocomial HCoV229E infections during the year 1998. Grey circles represent percentage of prevalence of infection in staff members. Three

epidemic periods of HCoV-related NRVI were observed in February, August and December, which correlated with a high prevalence of staff infection $(58.3,55$ and $21.4 \%$, respectively) 

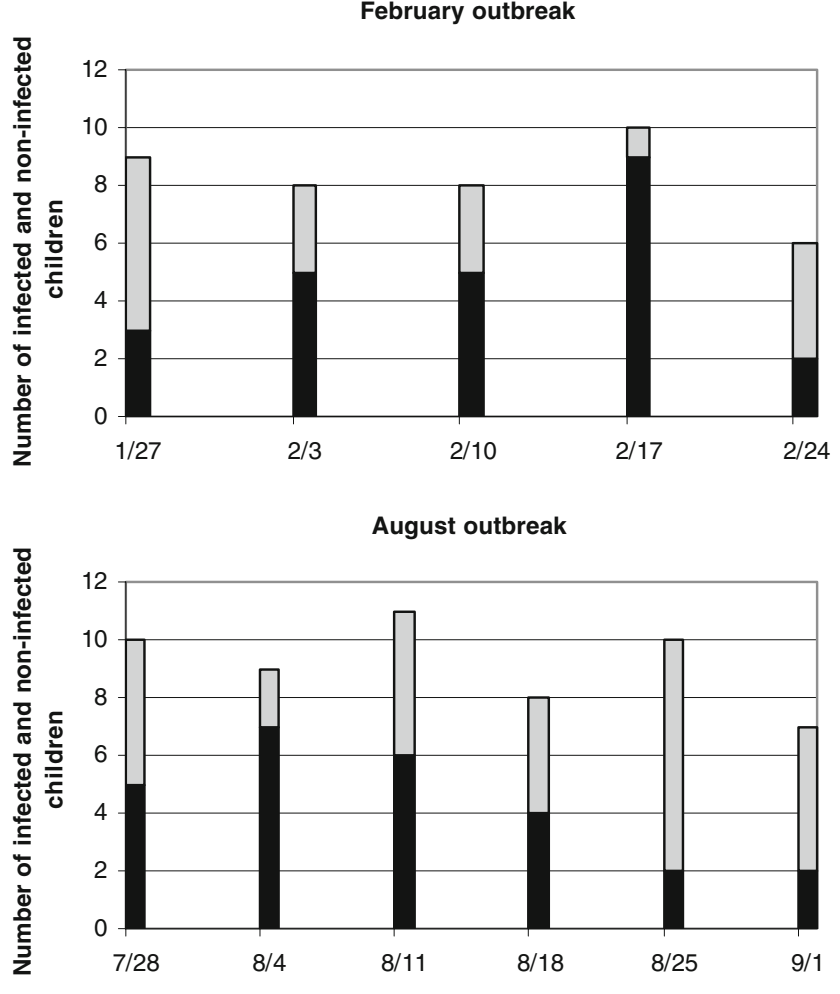

December outbreak

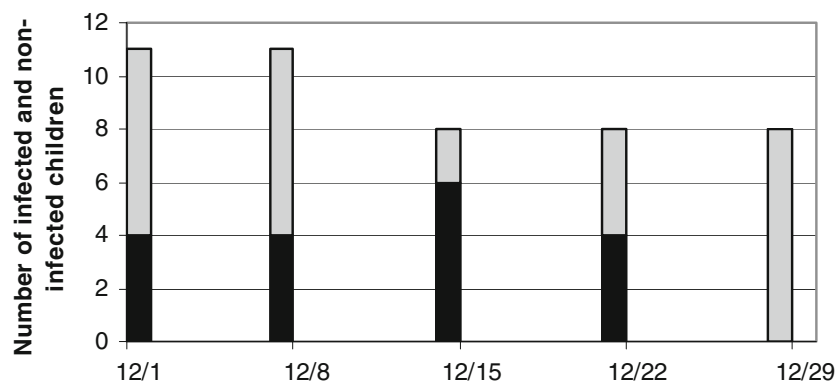

Fig. 2 Description of weekly outbreak periods in February, August and December. Black columns represent $\mathrm{HCoV}$-infected infants and grey columns non-infected infants. During these three outbreaks, 50 to $90 \%$ of hospitalised infants were infected with $\mathrm{HCoV}-229 \mathrm{E}$ acquired and nosocomial infections in this PNICU, and the quasi-exclusive virus involved in nosocomial infections in neonates, particularly premature neonates. The annual incidence of $\mathrm{HCoV}$ nosocomial infection in 1998 was $28.3 \%$ compared with $25 \%$ in 1995 and $11 \%$ in 1997 [9, 10, 33]. Annual incidence was lower in 1999 and 2001 with $22.3 \%$ and $19.5 \%$, respectively [38]. Thus, these $\mathrm{HCoV}$ nosocomial infections reflect the pattern of communityacquired infections with epidemic occurrence every 3 or 4 years as described by Monto et al. in sero-epidemiologic studies [20]. A high HCoV circulation in the community in 1998 could explain the high incidence of nosocomial infection in neonates as well as the three outbreak periods previously described.

Risk factors for $\mathrm{HCoV}$-nosocomial infection in neonates were essentially low birth weight and low gestational age. In fact, neonates with a high level of care were more susceptible to a nosocomial infection, and prematurity was the most important risk factor for nosocomial infection by $\mathrm{HCoV}$. Incidence of $\mathrm{HCoV}$-related infection in preterm neonates under 37 weeks, 33 weeks and 28 weeks was respectively $32 \%, 42 \%$ and $67 \%$. HCoV infection occurred in extremely premature neonates $(<28$ weeks) in two-thirds of cases. Maternal antibodies transported across the placenta protect the newborn, but most of these are acquired during the third trimester of pregnancy [41]. Most extremely premature neonates do not benefit from maternal antibody transfers and are more susceptible to neonatal viral infection [23, 27].

Seventy-five percent of neonates and $92 \%$ of extremely premature infants were symptomatic at the time of infection. The need for oxygen, ventilatory support and septic syndrome were the main clinical markers of viral infections in neonates $[22,23]$. These characterise the respiratory tropism of the $\mathrm{HCoV}$, but non-specific clinical manisfestations could also be present.In fact, in our previous studies, bradycardia and apnea were the most frequent signs of infection [32, 33].

Viruses are introduced in the hospital environment by visitors or staff who may or may not be symptomatic. $\mathrm{HCoV}$
Table 5 Point prevalence of staff infection

\begin{tabular}{llllll}
\hline Date & $\begin{array}{l}\text { Number of } \\
\text { collected } \\
\text { specimens }\end{array}$ & HCoV + & Prevalence (\%) & $\begin{array}{l}\text { Respiratory } \\
\text { symptoms (\%) }\end{array}$ & $\begin{array}{l}\text { HCoV + and } \\
\text { respiratory } \\
\text { symptoms }\end{array}$ \\
\hline 20 January 1998 & 24 & 13 & 54.2 & 8.3 & $2 / 13$ \\
24 February 1998 & 24 & 14 & 58.3 & 16.7 & $2 / 14$ \\
24 March 1998 & 23 & 6 & 26 & 13 & $2 / 6$ \\
14 April 1998 & 19 & 1 & 5.3 & 42.1 & $0 / 1$ \\
25 June 1998 & 18 & 8 & 44.4 & 11.1 & $1 / 8$ \\
4 August 1998 & 20 & 12 & 55 & 10 & $2 / 11$ \\
29 September1998 & 18 & 1 & 5.6 & 44.4 & $1 / 1$ \\
9 November 1998 & 20 & 1 & 5 & 40 & $0 / 1$ \\
21 December 1998 & 14 & 3 & 21.4 & 7.1 & $0 / 3$ \\
\hline
\end{tabular}


are able to survive in aerosol particles, in suspension and after drying $[15,34]$. Therefore, horizontal transmission via air or hand contamination is possible. In this study, the HCoVrelated outbreak periods correlated with a high prevalence of HCoV-related staff infections. Correlation between a high level of infected staff and a NRVI outbreak was previously described for RSV [12]. Moreover, intensive levels of care require increased handling and contact by personnel. For example, intubations and use of nasogastric tubes appear to be significant risk factors for NRVI [12]. The spread of infection from infected staff to patients during an adenovirus outbreak in a neonatal nursery has also been reported by Finn et al. [7]. $\mathrm{HCoV}$ are ubiquitous pathogens that very commonly infect the general population. Moreover, a high $\mathrm{HCoV}$ circulation may have occurred in the community in 1998. This could easily explain a high prevalence of infections in staff members and consequently the high level of $\mathrm{HCoV}$-related infections in neonates and premature infants who are in close contact with infected staff members. However, this study did not detect any cross-infection of infected children at time of admission to the unit with classic respiratory viruses such as RSV or influenza, as no nosocomial infections were detected with those viruses. The specific architecture of the unit with single separate rooms for each neonate may have contributed to this absence of cross-infection, as the minimum recommended area of $80 \mathrm{feet}^{2}\left(7.4 \mathrm{~m}^{2}\right)$ per neonate is respected [1]. This layout of distinct and separate sectors has proven efficient in the prevention of nosocomial RSV infections [35].

These data provide additional evidence for a possibly significant role of $\mathrm{HCoV}$ in NRVI occurring in hospitalised preterm neonates. Routine detection of $\mathrm{HCoV}$ in light of clinical worsening should be proposed to improve clinical management of neonates in the PNICU, thereby limiting unnecessary antibiotic use. Staff members may be involved in transmission of these viral infections. Since the infection may be asymptomatic in staff members, implementation of strict preventive measures against the spread of infection is more difficult, but nevertheless very important to protect the health of these infants.

Acknowledgments This study was supported in part by research funds from the French Ministry of Health, the CCLIN Ouest and the Société Française de Pédiatrie. We would like to thank Anne Gagneur, Marie-Annick L'Her, Michèle Odermatt and Christine Roger for excellent technical assistance, PNICU staff members and Tracey Montagnon for reviewing the manuscript.

\section{References}

1. (1995) Recommended standards for hospital resources, maternal and newborn care. In: Winnipeg (eds) Manitoba CoPaso, Mannitoba (http://www.phac-aspc.gc.ca/dca-dea/publications/ fcmc10_e.html)
2. Allander T, Tammi MT, Eriksson M, Bjerkner A, TiveljungLindell A, Andersson B (2005) Cloning of a human parvovirus by molecular screening of respiratory tract samples. Proc Natl Acad Sci USA 102:12891-12896

3. Barnes SD, Leclair JM, Forman MS, Townsend TR, Laughlin GM, Charache P (1989) Comparison of nasal brush and nasopharyngeal aspirate techniques in obtaining specimens for detection of respiratory syncytial viral antigen by immunofluorescence. Pediatr Infect Dis J 8:598-601

4. Boucher A, Desforges M, Duquette P, Talbot PJ (2007) Long-term human coronavirus-myelin cross-reactive T-cell clones derived from multiple sclerosis patients. Clin Immunol 123:258-267

5. Chany C, Moscovici O, Lebon P, Rousset S (1982) Association of coronavirus infection with neonatal necrotizing enterocolitis. Pediatrics 69:209-214

6. Esper F, Weibel C, Ferguson D, Landry ML, Kahn JS (2005) Evidence of a novel human coronavirus that is associated with respiratory tract disease in infants and young children. J Infect Dis 191:492-498

7. Finn A, Anday E, Talbot GH (1988) An epidemic of adenovirus $7 \mathrm{a}$ infection in a neonatal nursery: course, morbidity, and management. Infect Control Hosp Epidemiol 9:398-404

8. Freymuth F, Vabret A, Brouard J, Toutain F, Verdon R, Petitjean J, Gouarin S, Duhamel JF, Guillois B (1999) Detection of viral, Chlamydia pneumoniae and Mycoplasma pneumoniae infections in exacerbations of asthma in children. J Clin Virol 13:131-139

9. Gagneur A, Legrand MC, Picard B, Baron R, Talbot PJ, de Parscau L, Sizun J (2002) Nosocomial infections due to human coronaviruses in the newborn. Arch Pediatr 9:61-69

10. Gagneur A, Sizun J, Vallet S, Legr MC, Picard B, Talbot PJ (2002) Coronavirus-related nosocomial viral respiratory infections in a neonatal and paediatric intensive care unit: a prospective study. J Hosp Infect 51:59-64

11. Gerna G, Percivalle E, Sarasini A, Campanini G, Piralla A, Rovida F, Genini E, Marchi A, Baldanti F (2007) Human respiratory coronavirus HKU1 versus other coronavirus infections in Italian hospitalised patients. J Clin Virol 38:244-250

12. Hall CB, Douglas RG Jr (1981) Modes of transmission of respiratory syncytial virus. J Pediatr 99:100-103

13. Hamre D, Procknow JJ (1966) A new virus isolated from the human respiratory tract. Proc Soc Exp Biol 121:190-193

14. Han TH, Chung JY, Kim SW, Hwang ES (2007) Human Coronavirus-NL63 infections in Korean children, 2004-2006. J Clin Virol 38:27-31

15. Ijaz MK, Brunner AH, Sattar SA, Nair RC, Johnson-Lussenburg CM (1985) Survival characteristics of airborne human coronavirus 229E. J Gen Virol 66(Pt 12):2743-2748

16. Johnston SL, Pattemore PK, Sanderson G, Smith S, Lampe F, Josephs L, Symington P, O'Toole S, Myint SH, Tyrrell DA, Holgate ST (1995) Community study of role of viral infections in exacerbations of asthma in 9-11 year old children. Bmj 310:1225-1229

17. Ksiazek TG, Erdman D, Goldsmith CS, Zaki SR, Peret T, Emery S, Tong S, Urbani C, Comer JA, Lim W, Rollin PE, Dowell SF, Ling AE, Humphrey CD, Shieh WJ, Guarner J, Paddock CD, Rota P, Fields B, DeRisi J, Yang JY, Cox N, Hughes JM, LeDuc JW, Bellini WJ, Anderson LJ (2003) A novel coronavirus associated with severe acute respiratory syndrome. N Engl J Med 348:1953-1966

18. Kupfer B, Simon A, Jonassen CM, Viazov S, Ditt V, Tillmann RL, Muller A, Matz B, Schildgen O (2007) Two cases of severe obstructive pneumonia associated with an HKU1-like coronavirus. Eur J Med Res 12:134-138

19. Kuypers J, Martin ET, Heugel J, Wright N, Morrow R, Englund JA (2007) Clinical disease in children associated with newly described coronavirus subtypes. Pediatrics 119:e70-e76 
20. Lina B, Valette M, Foray S, Luciani J, Stagnara J, See DM, Aymard M (1996) Surveillance of community-acquired viral infections due to respiratory viruses in Rhone-Alpes (France) during winter 1994 to 1995. J Clin Microbiol 34:3007-3011

21. McIntosh K, Becker WB, Chanock RM (1967) Growth in suckling-mouse brain of "IBV-like" viruses from patients with upper respiratory tract disease. Proc Natl Acad Sci USA 58:22682273

22. Modlin JF (1986) Perinatal echovirus infection: insights from a literature review of 61 cases of serious infection and 16 outbreaks in nurseries. Rev Infect Dis 8:918-926

23. Moisiuk SE, Robson D, Klass L, Kliewer G, Wasyliuk W, Davi M, Plourde P (1998) Outbreak of parainfluenza virus type 3 in an intermediate care neonatal nursery. Pediatr Infect Dis J 17:49-53

24. Monto AS, Lim SK (1974) The Tecumseh study of respiratory illness. VI. Frequency of and relationship between outbreaks of coronavirus infection. J Infect Dis 129:271-276

25. Myint S (1995) The coronaviridae. Shiddell SG. Plenum Press, New York

26. Peiris JS, Tang WH, Chan KH, Khong PL, Guan Y, Lau YL, Chiu SS (2003) Children with respiratory disease associated with metapneumovirus in Hong Kong. Emerg Infect Dis 9:628-633

27. Rabkin CS, Telzak EE, Ho MS, Goldstein J, Bolton Y, Pallansch M, Anderson L, Kilchevsky E, Solomon S, Martone WJ (1988) Outbreak of echovirus 11 infection in hospitalized neonates. Pediatr Infect Dis J 7:186-190

28. Resta S, Luby JP, Rosenfeld CR, Siegel JD (1985) Isolation and propagation of a human enteric coronavirus. Science 229:978-981

29. Riski H, Hovi T (1980) Coronavirus infections of man associated with diseases other than the common cold. J Med Virol 6:259-265

30. Sizun J, Arbour N, Talbot PJ (1998) Comparison of immunofluorescence with monoclonal antibodies and RT-PCR for the detection of human coronaviruses 229E and OC43 in cell culture. J Virol Methods 72:145-152

31. Sizun J, Gagneur A, Legrand MC, Baron R (2001) Respiratory coronavirus infections in children. Pediatr Infect Dis J 20:555-556
32. Sizun J, Soupre D, Giroux JD, Alix D, De P, Legrand MC, Demazure M, Chastel C (1993) Nasal colonization with coronavirus and apnea of the premature newborn. Acta Paediatr $82: 238$

33. Sizun J, Soupre D, Legrand MC, Giroux JD, Rubio S, Cauvin JM, Chastel C, Alix D, de Parscau L (1995) Neonatal nosocomial respiratory infection with coronavirus: a prospective study in a neonatal intensive care unit. Acta Paediatr 84:617-620

34. Sizun J, Yu MW, Talbot PJ (2000) Survival of human coronaviruses 229E and OC43 in suspension and after drying onsurfaces: a possible source ofhospital-acquired infections. J Hosp Infect 46:55-60

35. Snydman DR, Greer C, Meissner HC, McIntosh K (1988) Prevention of nosocomial transmission of respiratory syncytial virus in a newborn nursery. Infect Control Hosp Epidemiol 9:105108

36. Vabret A, Dina J, Gouarin S, Petitjean J, Corbet S, Freymuth F (2006) Detection of the new human coronavirus HKU1: a report of 6 cases. Clin Infect Dis 42:634-639

37. Vabret A, Mourez T, Dina J, van der Hoek L, Gouarin S, Petitjean J, Brouard J, Freymuth F (2005) Human coronavirus NL63, France. Emerg Infect Dis 11:1225-1229

38. Vallet S, Gagneur A, Talbot PJ, Legrand MC, Sizun J, Picard B (2004) Detection of human Coronavirus 229E in nasal specimens in large scale studies using an RT-PCR hybridization assay. Mol Cell Probes 18:75-80

39. van der Hoek L, Pyrc K, Jebbink MF, Vermeulen-Oost W, Berkhout RJ, Wolthers KC, Wertheim-van Dillen PM, Kaandorp J, Spaargaren J, Berkhout B (2004) Identification of a new human coronavirus. Nat Med 10:368-373

40. Vernotte E, Legrand MC, Gagneur A, Salmon J, Sizun J, de Parscau L (1999) Asthma exacerbation: declenching role of coronaviruses is not confirmed. Arch Pediatr 6:583s

41. Zinkernagel RM (2001) Maternal antibodies, childhood infections, and autoimmune diseases. N Engl J Med 345:13311335 